回転後眼振，温度眼振とも固視抑制正常. IV回転後眼 振，温度眼振とも固視抑制過少。やはり検索し得た全 48例中26例と最も多くIの両者とも固視抑制過剩を諗 めた。

まとめ 動摇病発現機序に関してはこれまでに数々 の報告を認めるものであるが，それを最も説明し得る 説の 1 つとして感覚不均衡説が挙げられる.われわれ
の結果においても固視抑制過乘を多く認めたのは, 視 覚と耳石器, 三半規管を中心とした前庭系との間の前 庭小脳における不均衡を示す所見か。いずれにせよ興 味深いものである。また動摇病患者検索には, 上り適 刺激である回転刺激を示し，しかも刺激が微弱で，微 弱な病変も反映し得る回転後眼振を用いたVisual Suppression Testが適したものであると思われる。

\title{
105. 水浸による回転後眼振と温度眼振の影響
}

\author{
井上雄一郎・羽柴基之・馬場駿吉（名市大）渡辺 悟（名大環境医学研究所） \\ 系魚川文広（名工大）
}

はじめに 前庭動眼反射は体性感覚系（皮膚感賞， 足底感覚，関節感覚）の求心性入力により影響をうけ ると思われる。このような体性感覚の入力を減ずるよ うな低重力環境において前庭動眼反射がどのような影 響をうけるかを水浸法によって奉験したので報告し た。水浸法は扁まで水を浸水させることにより，浮力 による体重隇少を利用した低重力環境シミュレーショ ン法である。

方法 前庭刺激には回転刺激と温度刺激を用いた。 また前庭系と自律神経系の関係をみるために心電図， 較正脈波，呼吸数も同時に記録した。回転刺激には18 歳から43歳の健康な男性 5 人, 19 歳加ら21歳までの健 康な女性 3 人の計 8 人, 温度刺激には 18 歳加ら 22 歳ま での健康な男性 5 人を用いた。実験は被験者を水槽の 中の回転台の上に起立させ, 開眼状態でゴークルにて 視覚刺激を遮断した。回転刺激として被験者を起立姿 勢の状態で回転台を 1 分間 $1^{\circ} / \mathrm{sec}^{2} て ゙$ 加速させ約 $7 \mathrm{rpm} の$ 定速回転にて 1 分間回転させた後急速停止さ せ，それによって誘発される回転後眼振を記録した。 回転刺激の仕方として左右それぞれ 4 回転させ， 1 , 4 回目の左右回転は水浸していない状態で $2 ， 3$ 回目 の左右回転は水漫した状態で行った。また回転刺激時 の自律神経系の状態と比較するため回転前, 水浸直後, 排水直後, 実験終了時に静止状態をもうけた。なお水 の温度は $34^{\circ} \mathrm{Cを}$ を保った。温度刺激としては，被験者の 右外耳道に $30 \mathrm{ml}, 20^{\circ} \mathrm{C}$ 冷水を 20 秒間で注入し, 誘発 される温度眼振を記録した。温度刺激の仕方として， まず水浸していない状態で行い，次に水浸した状態で
行った. また実験開始前, 水浸直後, 排水後に静止状 態をもうけた。

結果及び考察 回転及び温度眼振のパラメーターと して眼振の最大緩徐相速度を使用した。 データの解析 法として回転, 温度眼振とも非水浸時の眼振の最大緩 徐相速度を基準100\%として水浸時の眼振值が何\%增 減したかを計算した。結果として，回転後眼振の最大 楥徐相速度においては水浸時と非水浸時との間に左右 回転とも有意差を示さなかったが，温度眼振において 5 人のデータのうち 4 人のデータが水漫時には温度眼 振の最大緩徐相速度の増加を認め有意差を示した。こ の結果により前庭系に強い刺激となる温度眼振におい ては水浸法による体性感覚の入力を減ずると前庭動眼 反射が促進されることがわかった。しかし回転後眼振 では有意差を示さなかった。これは回転速度が $7 \mathrm{rpm}$ と遅く, 前庭刺激として強いものではなかったからて はないかと思われる。な招自律神経系との関係は現在 検討中である。質問 時田 喬(岐大). 1) 眼振紱 徐相速度以外振幅, 急速相速度などの変化はどうか。 2）四肢位が眼振に影響すると思うが検查していたら 教えてほしい．3）水浸による眼振の変化には自己受 容性刺激, 圧刺激などの影響があると思うが何が重要 か. 応答 1) 緩徐相速度がめまい感を良く表すの でパラメーターとして用いた.2）水浸中四肢の状態の 変動を行ってはいない。 また水浸中は四肢はぐらつか ないように固定した.3）圧変化における眼振の変化は 考慮にいれなければならない、現在検討中である。

\section{6. 末梢性めまい患者の頭振り眼振と回転検査で 認められる眼振左右差との関係}

\author{
西村哲也・朴沢二郎・藤原文明・一條宏明 (弘前大)
}

目的頭振り眼振により推測される迷路病態の変化 が回転検査の成績とどのように関連するのかを知る目 的で, 一側末梢前庭障害例に頭振り眼振検查と回転検
查を同時に施行し，その結果を比較検討した。

方法 一側末梢前庭障害例 55 例 (検査件数 122 件) に まずコントラバス台形方式コンピューター回転検查を 
施行し，次いで頭振り眼振唡查をフレンツェル眼鏡装 着下に往復30回 15 秒振幅 $90^{\circ}$ で施行し ENG 記録し た。両検查により得られた眼振方向を比較し，回転検 査で認められる眼振左右差すなわち迷路優位性 (DP) と頭振り眼振の関係について検討した。更に頭振り眼 振第一相の方向がDPの方向と一致した症例について は，次に示すパラメーターを用いて両者に相関関係が 見られるかどうか検討した。すなわち，頭振り眼振検 查では持続時間 (sec) 及び最大緩徐相速度 $\left(\% / \mathrm{sec}^{2}\right)$ の2つを強さのパラメーターとし, 回転検査では眼振 持続時間の左右差 $(\mathrm{sec})$ 及び最大緩徐相速度の左右差 (\%)の2つをパラメーターとしてこれらを各々比較し た.また，メニエール病の経過中に患側迷路優位性を 示したものについて頭振り眼振との関係について検討 した.

結果 1. 眼振方向の比較では，1）回転検㚗で健側 迷路優位性を示す時, 37件中25件 $(68 \%)$ は同一方向 に第一相を持つ頭振り眼振が出現した.2）同様に患側 迷路優位性を示す時, 50 件中 30 件 $(60 \%)$ は同一方向
に第一相を持つ頭振り眼振が出現した.3）同様に前庭 補允現象を示す時, 21 件中 9 件 $(43 \%)$ は同一方向に 第一相を持つ頭振り眼振が出現したが，患側向き一相 性頭振り眼振が 6 件 $(29 \%)$ 出現した。2. 眼振第一相 の方向が DP と一致した頭振り眼振について,1) 頭振 り眼振の強さを持続時間で表した場合，回転眼振左右 差との間に相関関係はみられなかった.2）頭振り眼振 の強さを最大緩徐相速度で表した場合，回転眼振左右 差との間に正の相関関係がみられた（回転眼振持続時 間左右差：健側 $r=0.53(n=20)$ 患側 $r=0.36(n=22)$, 回転眼振最大緩徐相速度左右差: 健側 $r=0.53(n=$ 20) 患側 $r=0.58(n=18))$. 3. メ二エール病の経過中 に患側迷路優位性を示したものでは，32件中22件（68 \%)に同一方向に第一相を持つ頭振り眼振が出現した. 以上より頭振り眼振検査を末梢性前庭障害例に施行し た場合，コンピューター回転椧查によって眼振左右差 を認めた症例の約 $60 \%$ は回転検查と同様に迷路病態の 変化を推測出来ると思われ，頭振り眼振検查は外来で 簡便に出来る有用な検査となり得ると思われた。

\section{7. 回復眼振の臨床的意義について}

\section{調 重昭 - 山崎恵三・宮城司道 - 今村明秀（福岡大）}

一側の急性に起こった前庭障害の程度が高度である メニエール病・内耳炎・内耳振盪症・ラムセイハント 症候群・前庭神経炎などは発病からの比較的短時間に irritableな患側向きの眼振がみられ, やがて健側向き の眼振に移行する.さらに経時的に眼振を観察すると, 自覚症状の消失期にふたたび患側向きの眼振がみられ ることがあり，Stenger (1959) は回復眼振として記載 している. 自発ちよび頭位眼振で回復眼振がある時期 における自覚症状や温度眼振との検討や，頭振り眼振 との比較研究がなされているが，今回はこの他に傾斜 刺激により解発される眼振 (傾斜眼振) との対比を行 い，回復眼振の臨床的意義について検討した。

2 -3 力月毎にめまい発作を反復している発病以来 $5-6$ 年を経過したメ二エール病の一症例において, 発作期と寛解期に患側向きの傾斜眼振が観察された。 いわゆる間歇期には自発・頭位眼振検查ではほとんど 眼振がなくても，傾斜眼振でははっきりと認められ， 他の眼振検查の結果との関連で回復眼振かどうかを判 定できた，突発性難聴でも自覚症状や頭位眼振のみら れる短時間に患側向き，その後健側向きとなり，再び 患側向きの傾斜眼振がみられることがあるが，障害部 位や程度の多様性によるものか, 必ずしも一定の傾向 がみられなかった，発症後数力月を経たラムセイハン 卜症候群で，自発・頭位眼振は既に消失しているのに 患側向きの傾斜眼振をみた数症例を観察している，40
歳・家婦の前庭神経炎の症例では，健側向きの自発・ 頭位眼振が数週間持続していたが，自覚症状や頭位眼 振が消失し，温度眼振反応が正常化するとともに傾斜 眼振が患側向きになったのを記録した。

傾斜眼振を含めて一側前庭障害例の眼振の推移を検 討した結果，傾斜眼振は自発眼振や頭位眼振よりも， より鋭敏に動眼系の回復過程を表出するものと思われ た。また診断的意義としては，頭位眼振検查や傾斜検 查で回復眼振がみられたら，一側末梢性の前庭障害と みなし得ること，また他の眼振検査や傾斜眼振との相 関で,発作期・回復期などの病期の判定もより詳細にで きることが分かった，しかし基本的には各末梢性めま い疾患における回復眼振の定義や意味づけ，また傾斜 眼振でみられる患側向き眼振の意義についてはさらに 全般的な検討も必要である。質問 時田 意(岐 大). 傾斜による眼振の発現機転について. 前庭神経炎 例で自発・頭位眼振と傾斜眼振との性質の差は何によ るものか. 応答 前庭中枢の機序に対する傾斜刺 激の影響を検討したわけで，傾斜刺激による眼振は耳 石器作用による眼球偏倚と関係があると思われる。

質問 藤原文明(弘前大)。傾斜刺激による患側向き眼 振は, 突発性難聴において, 聴力の回復期あるいは回 復する聴力の周波数との関連はあるか. 応答 突 発性難聴の難恥回復と回復眼振の出現は関連しないと の印象である。 